\title{
Pilot study of air quality index assessment of nitrogen pollutant using lichen as bioindicators in Jakarta and Depok, Indonesia
}

\author{
Davita Adryanti Felicia Sampe ${ }^{1}$, Jessye Maria-Deanne Awuy ${ }^{1}$, Trifena Krista Mustikaning \\ Sekar ${ }^{1}$, Samuel Febrian Wijaya ${ }^{1}$, Alyssa Zahwa Ananda ${ }^{1}$, Devina Trisha Marella ${ }^{1}$, Putra \\ Mahanaim Tampubolon ${ }^{1}$, and Retno Lestari ${ }^{1 *}$ \\ ${ }^{1}$ Microbiology Study Group Proteus, Departement of Biology, Faculty of Mathematics and Sciences, \\ Universitas Indonesia, Depok, 16424, Indonesia
}

\begin{abstract}
Indonesia needs an alternative air quality index considering that the ones currently in use were not precisely made for the environment and people's genetic makeup in Indonesia. This study aims to determine if lichen can be used as an alternative index to assess Indonesia's air quality by acting as a bioindicator. Lichen samples were taken at six locations, three in Gelora Bung Karno's City Forest, Jakarta, and three at the Universitas Indonesia's city forest, Depok. Lichens are identified according to the chemical test results and identification key. The amount of lichen obtained is calculated and converted into a NAQI chart to determine if the site's status is clean air, at-risk, N-polluted, or very $\mathrm{N}$-polluted location. Two of them are polluted by nitrogen from seven sampling areas, while the other five are heavily polluted. This data shows the air quality in all areas is insufficient and polluted. However, our findings are contradictory to nitrogen pollutant data from Meteorology Climatology and Geophysics Council (BMKG). Thus, in the future, there should be a calibrator when measuring air quality analysis using lichen.
\end{abstract}

\section{Introduction}

Concern regarding Jakarta's air quality recently elevated due to citizens' awareness of the Air Quality Index (AQI). AQI is an understandable and straightforward index for air quality assessment and the health effects for humans. Citizens can easily access real-time AQI from applications in their smartphones, such as AirVisual. Based on AirVisual, the air quality value of Jakarta in 2019 was generally within the range of 101-200, which was categorized as "unhealthy and harmful for sensitive groups." However, one single index, as shown in AirVisual, cannot entirely represent air quality in the atmosphere. Another air quality index is needed for comparison to assess air quality value by their surroundings on their own. This case could prevent misunderstanding and unnecessary panic among citizens caused by AQI's air quality assessment information [1].

\footnotetext{
* Corresponding author: retno.lestari@sci.ui.ac.id
} 
The generally used AQI in Indonesia is based on an air quality index in the United States (US). It is based on a long-term study regarding the correlation between air pollution in the US and its citizens' health state. However, AQI does not entirely reflect Indonesia's air quality since there are differences in environmental factors and genetic makeup between the US and Indonesia. Every country must consider their local circumstances specifically, therefore having different classes and the threshold value for their AQI [2]. Many countries have already had their air quality index; for example, Air Quality Health Index by Canada, Air Pollution Index by Malaysia, Pollutant Standards Index by Singapura, and Air Quality Health Index by Hong Kong [3-5].

Through the Directorate of Air Pollution Control, Indonesian Governance, Ministry of Environment and Forestry have already released their AQI for Indonesia, Standard Air Pollutant Index (ISPU). ISPU uses some pollutants as parameters, such as particulate matter 10 (PM10), carbon monoxide (CO), sulfur dioxide $\left(\mathrm{SO}_{2}\right)$, nitrogen dioxide $\left(\mathrm{NO}_{2}\right)$, and ozone $\left(\mathrm{O}_{3}\right)$. ISPU has similarities with US AQI regarding the descriptive categories and range index values, but ISPU does not show real-time information. Based on ISPU, the air quality of Indonesia in 2019 is generally classified as healthy. Unlike the US AQI value, ISPU considers the correlation between the environmental condition and the people's wellbeing, which represents more of Indonesia's air quality. However, ISPU has not gained popularity as much as US AQI. Citizens prefer to assess US AQI's air quality since it is widely known and accessible from websites and applications [6].

The most popular website used to monitor real-time air quality in Indonesia is AirVisual. However, AirVisual determines the overall AQI number based only on primary air pollutants. Out of 6 main pollutants, PM2.5 is the primary pollutant for most locations, thus shown on the website. The combined impact of low-level exposure pollutants and multi pollutants, particularly nitrogen, needs to be considered to prevent long term effects and any other late-onset health issues [2].

An excessive amount of nitrogen in the air can cause various health issues and disturbs the surrounding ecosystem. The main contributors to the air's high nitrogen level are agricultural activities and fossil fuel combustion in motor vehicles. Pollutants are measured mechanically using automatic chemiluminescence analyzer or diffusion tubes to determine the air's nitrogen level [7-8]. Several types of health effects have been discussed and studied in correlation to exposure to nitrogen oxides. Studies regarding the association between nitrogen dioxide exposure and respiratory symptoms conclude that nitrogen dioxide acts as an irritant that affects the respiratory tract [9]. High nitrogen levels also affect the environment with well-known effects: including ecological imbalance such as algal blooms in lakes or coastal areas and biodiversity loss. For that reason, nitrogen levels in the air can be measured by the state of the diversity of that ecosystem, specifically the bioindicator biodiversity [10].

Bioindicators are a species or a group of species that produce a reaction to ecological changes and can be used to assess the ecosystem [11]. Bioindicators can detect changes in their surroundings, whether it is natural or anthropogenic disturbances such as pollutants. Examples of prominent bioindicators are epiphytic bryophytes and lichens. Both are powerful air quality indicators, but lichens' widespread distribution makes them preferable [10-12]. Lichens are composite organisms made up of algae and fungi. The algae are the part that is responsible for the nutrient formation, while the fungi supply water and minerals [13]. Lichens obtain water and nutrients directly from the atmosphere, so the air pollutants around their surroundings, such as nitrogen and its oxides, significantly affect their survival. Species of lichens associated with high N levels were termed 'nitrophyte' and those associated with low $\mathrm{N}$ levels termed 'acidophyte [10,12].

Through a short process of lichen-indexing in a designated area, the level of air pollutants can be determined using the spectrum of lichen properties that can be tolerant or 
sensitive to a specific pollutant. In this case, abundant nitrogen-tolerant lichen means that the area may be polluted by nitrogen. Conversely, the presence of abundant nitrogensensitive lichen indicates that the area is still clean from nitrogen contamination. Examples of nitrogen-tolerant lichens are the Lecanora dispersa as well as Xanthoria candelaria. Meanwhile, the Lepraria incana and Parmelia saxatilis are categorized among nitrogensensitive lichens [12].

From previous studies, the quantitative calculation for air quality assessment using lichen had been done since 1970 by LeBlanc and DeSloover in Europe. They developed an index called Index of Atmospheric Purity (IAP), which was later developed by other European countries such as German and Italy. Values of IAP vary from 5.9 to 71.7, divided into five categories of air quality [14-15]. The total lichen air quality score in a study for air quality index using lichens in Malaysia. is divided into four categories, the score above ten means the air is clean, while the score below -10 means the air is highly polluted [16]. Furthermore, a pollution index based on the abundance of acidic lichen species from the Northeast US has also been researched. This index ranged from 0 for the cleanest air to 2 for the dirtiest air [17]. There also had been studies using lichen as a bio-indicator of air quality in certain parts of Indonesia, such as Bogor and Surabaya [18, 19]. However, research on lichen diversity and its correlation with air quality has not been done in Jakarta and Depok.

The ability of lichen to determine nitrogen pollution could be an alternative to measuring Jakarta and Depok's nitrogen levels. This method also provides a biological measurement to assess air pollution as an addition or alternative to the chemical and physical measurement provided by AQI, ISPU, or AirVisual.com. By assessing Ntolerant/ $\mathrm{N}$-sensitive lichens' biodiversity in certain areas, the nitrogen pollutant level data that was previously not identified by using AirVisual.com or ISPU alone would be available. When measuring air quality using lichen, this research use Nitrogen Air Quality Index (NAQI) developed by Wolseley et al. (2013) in the UK as a pilot study.

Nitrogen Air Quality Index (NAQI) is an index that shows the level of nitrogen pollutants in the atmosphere. NAQI, which is derived from Lichen Indicator Score (LIS), developed in the United Kingdom and was published in Guide to using a lichen-based index to nitrogen air quality. Recently, the NAQI calculation can be quickly done using an application called Lichen App, which was developed by the Centre for Ecology and Hydrology $(\mathrm{CEH})$. Lichen App provides a guide for identifying and recording the lichen community also auto-calculates the lichen score into LIS and NAQI [20, 37].

LIS is calculated based on N-sensitive and N-tolerant lichens' presence on the trunk and branch of oak or birch tree. Oak or birch trees are selected because they tend to have an acid trunk (pH 3-4). Trunk's pH affects the growth of the lichen community. N-sensitive lichen tends to grow on the acid trunk, and N-tolerant lichen tends to grow on the base trunk. The increasing nitrogen pollutant in the atmosphere leads to changes in the trunk's $\mathrm{pH}$ and the lichen community that grows on them. These changes will affect the index result later. Therefore, the NAQI calculation needs to be done on the lichen community on the trunks that tend to be acid. There have never been any studies regarding NAQI calculation based on lichen community that grows on other types of trees [20,38].

This study discusses the characteristics and nitrogen sensitivity categories of the lichen species found in UI (Depok) and Jakarta. This research collected lichen biodiversity data by identifying lichens species in UI (Depok) and Jakarta to find a correlation between air quality and lichen biodiversity. This research aims to find out whether lichen can act as a bioindicator to air pollution in Indonesia or not. LIS value was converted into NAQI. It will then be compared with data from Meteorology Climatology and Geophysics Council of Indonesia (BMKG) to see if using lichens can be a new bio-indicator of air quality. 


\section{Method}

This research method uses a quantitative descriptive method which compares the conditions of two locations with different characteristics. These two locations were chosen because of their proximity to human activities and suitable areas for sampling. The data gathered will go through chemical tests and a thorough identification. Finally, this method will be concluded by a description of data analysis using an air quality index.

\subsection{Research locations}

Lichen sampling was conducted at two separate locations, Jakarta and Universitas Indonesia, Depok. In each location, this research choose several sampling areas and labeled them. There were three sampling areas in Jakarta, North Honda Park (labeled as JKT 1), one side of Gelora Bung Karno (GBK) Stadium (labeled as JKT 2), and the other side of GBK stadium (labeled as JKT 3). In Universitas Indonesia, there were four sampling areas, UI's Student Dormitory (labeled as UI 1), a sidewalk near the campus' forest (labeled as UI 2 ), and the other two areas were near the Economy and Business Faculty. The third area was on the road between Economy Faculty and Makara Clinic (labeled as UI 3), and the fourth area was on the road near the Economy Faculty and Psychology Faculty (labeled as UI 4).

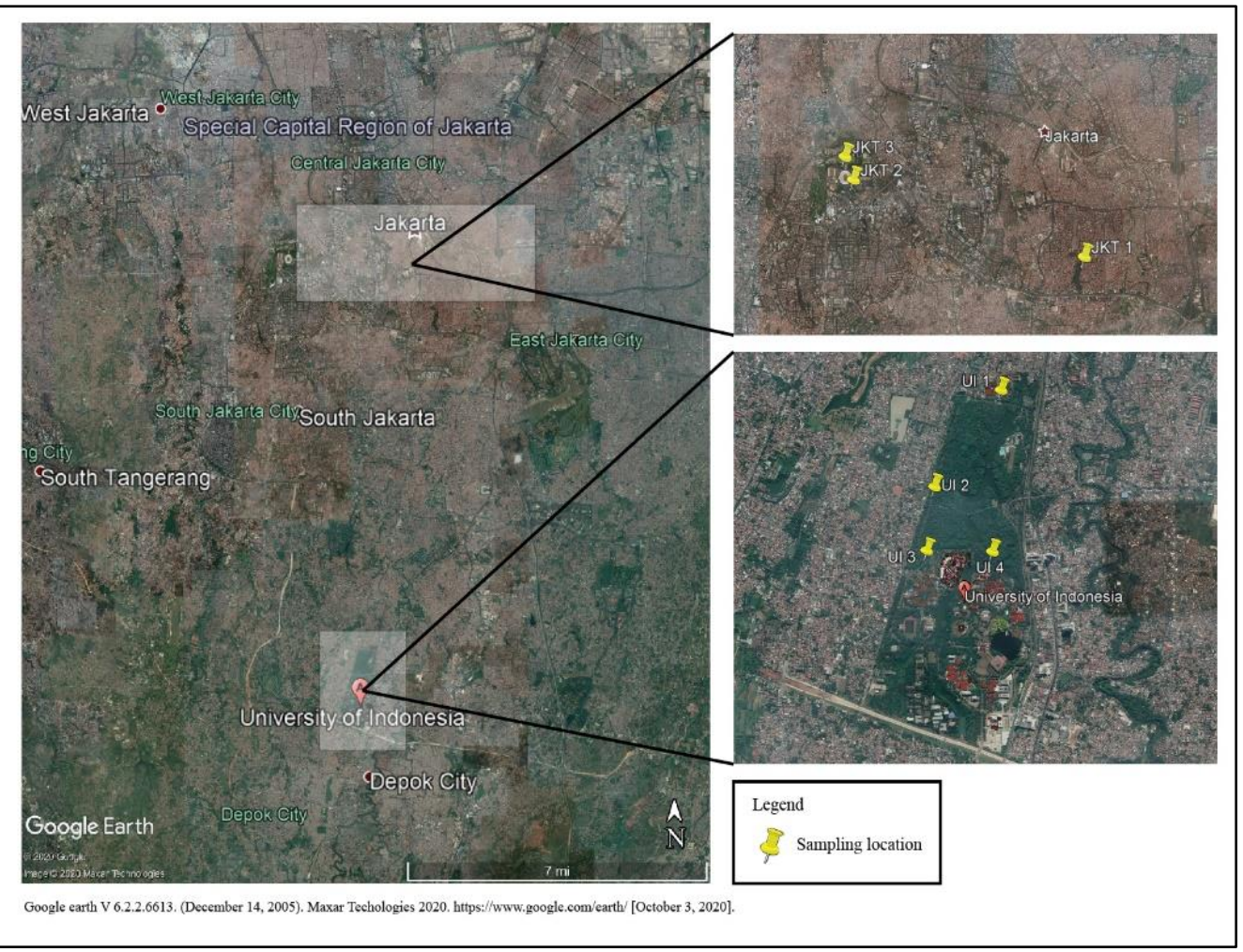

Fig. 1. Research locations in Jakarta and Depok (Source: Author's Analysis, 2020). 


\subsection{Data collection}

The following procedure took data collection. Samples were taken from at least 20 trees with more than $50 \mathrm{~cm}$ diameter on three sides: east, south, and west. On each side, sampling areas are made with transect $(10 \mathrm{~cm} \times 50 \mathrm{~cm})$. The lichens inside the transect were counted and documented. On-site chemical testing was also conducted. Documented lichens from various sides are analyzed whether they belong to the $\mathrm{N}$-sensitive or $\mathrm{N}$ tolerant lichen. These analyses are made based on lichen identification and the chemical test.

\subsection{Chemical test using $\mathrm{NaOH}$ and bleach}

Lichen contains various chemical compounds that can be used to identify its species or type. Hence, the on-sight biochemistry spot test is done using $\mathrm{NaOH}$ and bleach. In an accessible container, $150 \mathrm{ml} \mathrm{NaOH}(1 \mathrm{M})$ and $150 \mathrm{ml}$ bleach $(1 \mathrm{M})$ are prepared. Sterilized toothpicks are also prepared as needed, at least six toothpicks for each tree. The spot test is using a small amount of $\mathrm{NaOH} 1 \mathrm{M}$ is taken with a toothpick. Observed lichen will then be touched with $\mathrm{NaOH}$ smeared toothpick and wait until the lichen reacts. The same thing is done with bleach. Any change of colors should be observed, as several lichen species produce distinct colors when exposed to chemical compounds.

\subsection{Lichen identification}

The collected lichen samples are initially categorized based on their growth forms. There are three primary growth forms: bushy or fruticose lichens, leafy or foliose lichens, and crustose or granular lichens. The lichens are identified by studying and comparing their morphology based on the field manual [20].

\subsection{Data analysis using air quality index NAQI}

Lichen that has been identified at each location is then calculated by dividing the average number of N-tolerant and the average number of $\mathrm{N}$-sensitive. The resulting number is the Lichen Indicator Score (LIS). After that, the LIS results were converted to Nitrogen Air Quality Index (NAQI) using a regression line [21].

The NAQI regression line divides four groups, namely Clean air, At-risk, N-polluted, and Very N-polluted [21]. 'Clean air' shows that the tree has little N pollution. 'At-risk' indicates that there is a mixture of N-tolerant and N-sensitive lichen. 'N-polluted' shows that $\mathrm{N}$-tolerant species dominated the trees in the sampling site, but some $\mathrm{N}$-sensitive lichens still exist. 'Very N-polluted; shows that there is no N-sensitive lichen overall [21].

\section{Results and discussion}

\subsection{Ecological properties}

Based on the calculation results, the sampling location with the highest diversity value is the UI 4 area in the road near the Faculty of Economics and Business Universitas Indonesia. In contrast, the lowest diversity value is JKT 3, one side of Gelora Bung Karno Stadium. The location with the highest evenness value is JKT 3 because only one species was found, while the lowest evenness value is in JKT 2. he Simpson's diversity index is 
also calculated, which results in the location of JKT 2 having the highest value, while the lowest value is UI 4.

Table 1. Ecological Properties.

\begin{tabular}{|c|c|c|c|}
\hline Sampling location & $\begin{array}{c}\text { Shannon Weiner } \\
\text { Diversity Index }\end{array}$ & $\begin{array}{c}\text { Simpson's Diversity } \\
\text { Index }\end{array}$ & $\begin{array}{c}\text { Pielou's Evenness } \\
\text { Index }\end{array}$ \\
\hline UI 1 & 1.59 & 0.25 & 0.73 \\
\hline UI 2 & 1.47 & 0.31 & 0.76 \\
\hline UI 3 & 1.29 & 0.34 & 0.72 \\
\hline UI 4 & 1.70 & 0.20 & 0.87 \\
\hline JKT 1 & 1.07 & 0.40 & 0.67 \\
\hline JKT 2 & 0.57 & 0.68 & 0.41 \\
\hline JKT 3 & 0.00 & 1.00 & 0.00 \\
\hline
\end{tabular}

\subsection{Nitrogen sensitive and tolerant lichen percentage}

The two highest N-sensitive lichen percentages (12.34\%) were found at UI 1 area, followed by UI 3 area (10.53\%) (Table 2), while JKT 2 and JKT 3 showed the lowest percentage $(0.00 \%)$. The highest N-tolerant lichen percentage (100.00\%) was found at JKT 2 and JKT 3 , while the lowest percentage $(87.66 \%)$ was found at UI 1 area. Thoroughly, the percentage between $\mathrm{N}$-sensitive and $\mathrm{N}$-tolerant lichen was significantly lopsided, which was $3.66 \%$ to $96.34 \%$ (Table 2).

Table 2. N-Sensitive and N-Tolerant Lichen Percentage.

\begin{tabular}{|c|c|c|c|}
\hline Study Area & N Sensitive (\%) & N Tolerant (\%) & Grand Total (\%) \\
\hline UI 1 & 12.34 & 87.66 & 100.00 \\
\hline UI 3 & 0.28 & 99.72 & 100.00 \\
\hline UI 4 & 10.53 & 89.47 & 100.00 \\
\hline JKT 2 & 0.00 & 100.00 & 100.00 \\
\hline JKT 3 & 0.00 & 100.00 & 100.00 \\
\hline UI 2 & 0.07 & 99.93 & 100.00 \\
\hline JKT 1 & 1.00 & 99.00 & 100.00 \\
\hline Grand Total (\%) & 3.66 & 96.34 & 100.00 \\
\hline
\end{tabular}

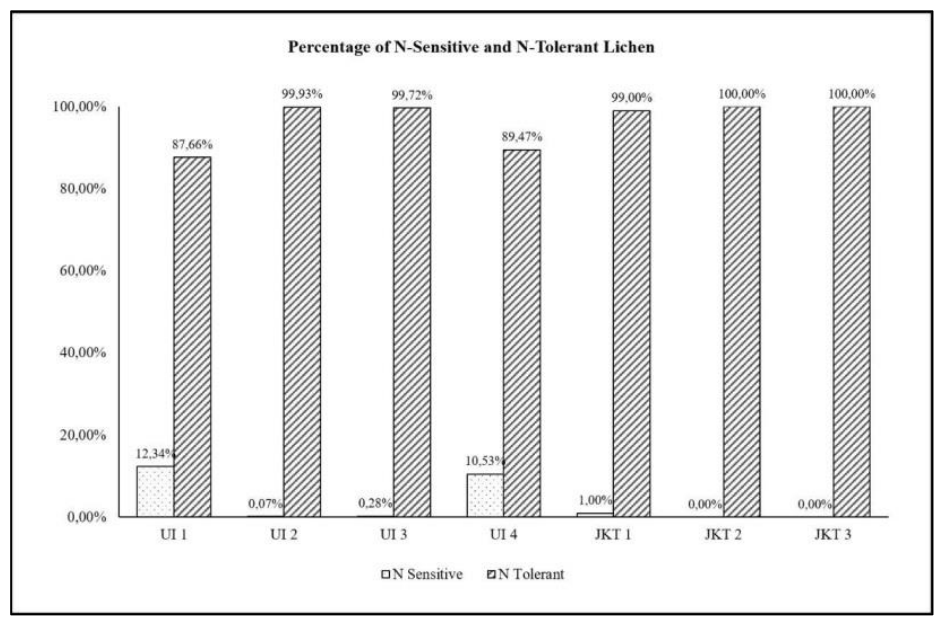

Fig. 2. Percentage of nitrogen sensitive and tolerant lichen in each sampling area. (Source: Author's Analysis, 2020). 


\subsection{Air quality assessment}

Evaluation of air quality was carried out by converting LIS to Nitrogen Air Quality Index (NAQI). The index can show if a particular area was polluted by nitrogen. Only two were nitrogen polluted from seven sampling areas, while the others were indicated as very nitrogen polluted. All the sampling area in Jakarta were indicated as very polluted by nitrogen. Two sampling areas at Universitas Indonesia, UI 1 and UI 4, were the location where the nitrogen pollutant was lower than the other areas. UI 2 and UI 3 sampling areas were significantly polluted by nitrogen. From the result, all the sampling area had already been polluted by nitrogen. The difference is only how high the degree of pollution in each area. The air was considered nitrogen polluted if it scored $0.85-1.25$ points on Nitrogen Air Quality Index. The area that scored higher than 1.25 points was considered very polluted with nitrogen.

Table 3. Air Quality analysis of each sampling area based on NAQI

\begin{tabular}{|c|c|}
\hline Sampling area & Air Quality Analysis \\
\hline UI 1 & N Polluted \\
\hline UI 2 & Very N Polluted \\
\hline UI 3 & Very N Polluted \\
\hline UI 4 & N Polluted \\
\hline JKT 1 & Very N Polluted \\
\hline JKT 2 & Very N Polluted \\
\hline JKT 3 & Very N Polluted \\
\hline
\end{tabular}

Universitas Indonesia had a great variety of lichen, 14 species were found in this location. Phlyctis argena was the most found lichen at UI 1 and UI 2, while Cryptotechia spp. was mostly encountered at UI 3, and at UI 4, Lepraria incana was the most encountered species. The lichens that were most abundant at each sampling area were identified as nitrogen tolerant species. At the sampling areas, several nitrogen sensitive lichens were also found, such as Graphis spp. However, their number was lower than the nitrogen tolerant species.

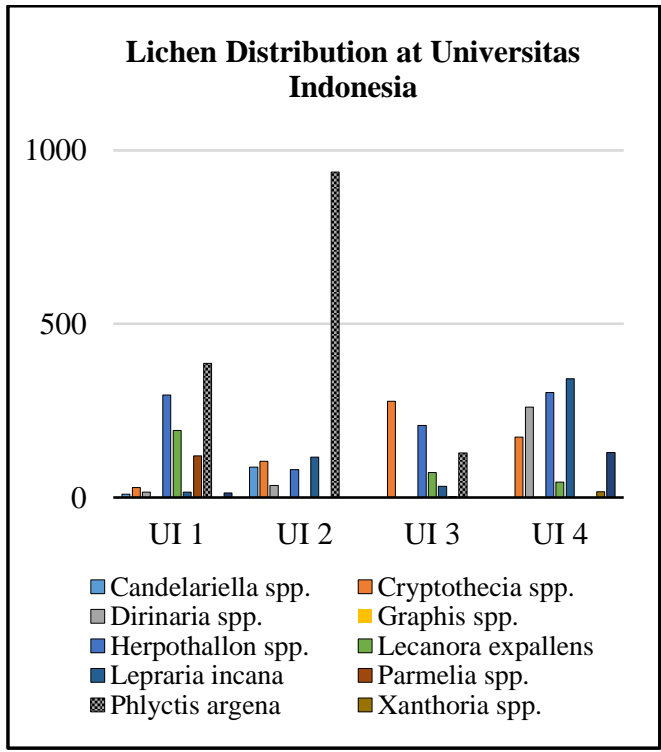

Fig. 3. Distribution of lichen species on each sampling area at Universitas Indonesia. (Source: Author's Analysis, 2020).

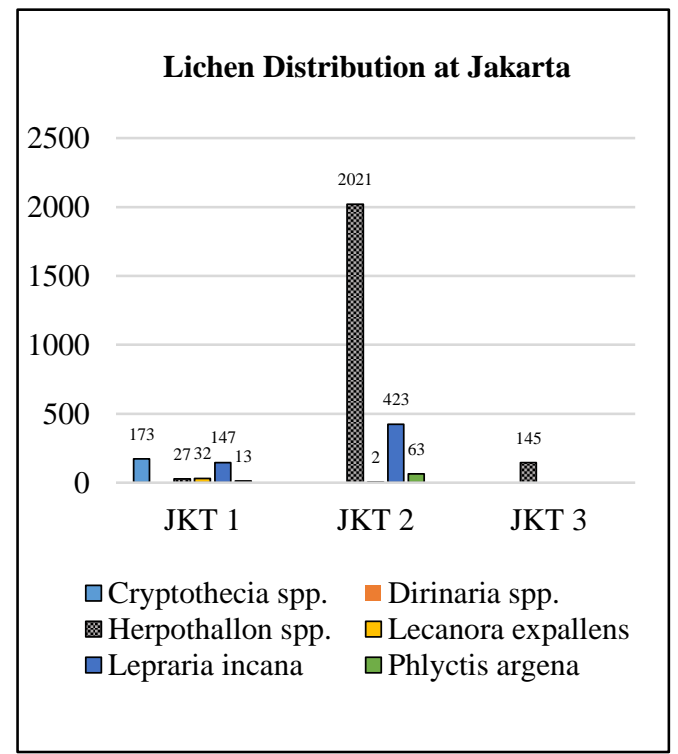

Fig. 4. Distribution of lichen species on each sampling area at Jakarta. (Source: Author's Analysis, 2020). 
At Jakarta, Herpothallon was the most found species. It was found at all sampling areas in Jakarta. Among the three areas, JKT 2 was the place that had the highest count of Herpothallon. At JKT 3, Herpothallon was the only species that was found. JKT 1 has the most diverse lichen species but has the lowest Herpothallon count compared to the other. Collectively, this research recorded less diverse lichen species in Jakarta compared to Universitas Indonesia.

\subsection{Lichen proportion on cardinal directions and two-way ANOVA test}

This study gathered samples from 20 trees and three cardinal directions, namely east, south, and west, in each area. The total of lichen wich was collected from each tree in all regions, both Universitas Indonesia and Jakarta, is also accumulated (Table 4). The number of lichens in the West and East does not significantly differ. However, in the southern area, there is a significant difference in the number of lichens. The statistical test was performed with the two-way analysis of variance (ANOVA) test to validate our interpretation. Results of two ways ANOVA inform that there is a statistically substantial difference in the total lichens of each tree in the three cardinal directions ( $p<0.0016, \mathrm{CI}=95 \%)$, but no difference between the west, south, and east lichen data groups for each tree $(\mathrm{p}=0.4235, \mathrm{CI}=95 \%)$.

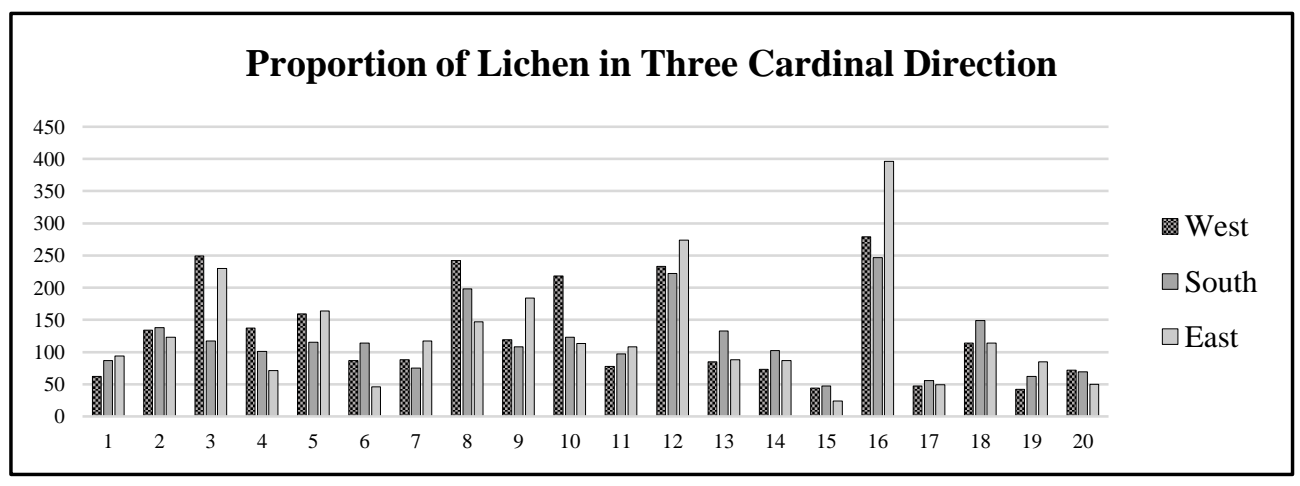

Fig. 5. The proportion of lichen on three cardinal directions in all areas. (Source: Author's Analysis, 2020).

Table 4. Distribution of Lichen on three cardinal direction.

\begin{tabular}{|c|c|c|c|c|}
\hline Trees & West & South & East & Total \\
\hline 1 & 62 & 87 & 94 & 243 \\
\hline 2 & 134 & 138 & 123 & 395 \\
\hline 3 & 249 & 117 & 230 & 596 \\
\hline 4 & 137 & 101 & 71 & 309 \\
\hline 5 & 159 & 115 & 164 & 438 \\
\hline 6 & 87 & 114 & 46 & 247 \\
\hline 7 & 88 & 75 & 117 & 280 \\
\hline 8 & 242 & 198 & 147 & 587 \\
\hline 9 & 119 & 108 & 184 & 411 \\
\hline 10 & 218 & 123 & 113 & 454 \\
\hline 11 & 78 & 97 & 108 & 283 \\
\hline 12 & 233 & 222 & 274 & 729 \\
\hline 13 & 85 & 133 & 88 & 306 \\
\hline 14 & 73 & 102 & 87 & 262 \\
\hline
\end{tabular}




\begin{tabular}{|c|c|c|c|c|}
\hline 15 & 44 & 47 & 24 & 115 \\
\hline 16 & 279 & 247 & 396 & 922 \\
\hline 17 & 47 & 56 & 49 & 152 \\
\hline 18 & 114 & 149 & 114 & 377 \\
\hline 19 & 42 & 62 & 85 & 189 \\
\hline 20 & 72 & 69 & 50 & 191 \\
\hline Total & 2562 & 2360 & 2564 & 7486 \\
\hline
\end{tabular}

\subsection{Discussion}

Based on research conducted on Pangkor Island, Malaysia, the lichen found is morphologically the same as lichens found at the Universitas Indonesia, and Jakarta, namely Dirinaria sp., Graphis sp., and Cryptothecia sp. Another research has also been carried out in Aceh, and it has been identified that there are lichens with the same morphology, namely Lepraria incana and Candelariella sp. Dirinaria sp. can be found in lowland areas as well as in locations with high traffic densities. Hence it is an N-tolerant lichen [22]. Dirinaria is a lichen with a wide distribution, especially in the tropics. This lichen thallus has a bluish-gray or whitish color with a width of up to $6 \mathrm{~cm}$. The lichen lobes of this species appear flat and overlap [23]. Lepraria incana is one of the lichens with a crustose thallus, powdery, and an N-tolerant lichen. This lichen has a greenish-gray color and is often found attached to bark, rocks, and walls [24]. Graphis sp. is a lichen with thallus in small lines and attached to the substrate [25]. Cryptothecia sp. has crustoseshaped thallus morphology, has a green and white coloration, and belongs to the $\mathrm{N}$-tolerant lichen group [26].

Research conducted by Hadiyanti [27] also found the same lichen species as the species found in this study, namely Parmelia sp. Parmelia sp. is a lichen with a foliose-shaped thallus. Parmelia sp. has supportive morphological structures to survive the conditions with high levels of pollutants [27]. In this study, Verrucaria maura were also found. This species forms a thin black layer on the rock surfaces [28]. While Parmelia sp. is an N-tolerant lichen, Verrucaria maura is an N-tolerant lichen [29].

Apart from the species already mentioned, the species Phlyctis argena, Lecanora expallens, Herpothallon sp., Xanthoria sp. were also found. Phlyctis argena is a crutose shaped lichen with a grayish-white thallus and reacts to $\mathrm{KOH}$ [30]. Lecanora expallens is a crutose shaped lichen with green or pale-yellow thallus. At first, this lichen will form a round shape, but the shape will become irregular [31]. Herpothallon spp. is a lichen that has a crustose-shaped thallus. This lichen has an irregular shape, green color, and attached to the substrate [32-33]. Xanthoria sp. has a foliose-subfruticose thallus, forms a rosette, and spreads on the substrate. This species has a color that mixes between orange and yellow [31].

While examining their morphological properties thoroughly, a pattern was observed. Sensitive lichen species tend to have foliose or leafy thallus than tolerant ones. Thus, crustose lichens have more tolerance towards pollution than foliose lichens [34]. Furthermore, studies show that sensitive lichens will produce more chlorophyll; hence they have deeper colors [35]. Therefore, there is a relationship between the morphological characteristics of lichen and its tolerance level. However, researches regarding tolerance levels of lichen for nitrogen pollution specifically has not been conducted yet so more research on this theme is needed in the future.

At each study area, lichens were identified and categorized based on their sensitivity to nitrogen pollutants resulted in figure 1, which showed a higher number of nitrogen-tolerant lichens than nitrogen-sensitive lichens. The JKT 1 and JKT 2 sites presented the most massive contrast with $100 \%$ nitrogen-tolerant lichen found in each site. The UI 1 site has 
the smallest contrast with $87.94 \%$ nitrogen-tolerant lichens to $12.06 \%$ of the nitrogensensitive lichens. The massive difference between $\mathrm{N}$-sensitive and $\mathrm{N}$-tolerant lichens is due to the high levels of nitrogen oxides present at each site, which only supported the growth of nitrophyte lichens that can tolerate high numbers nitrogen in their surroundings [12, 36]. Simultaneously, there is a loss of acidophytes or nitrogen-sensitive lichens as they cannot survive amidst the high levels of nitrogen pollutants in the air [36]. Amongst the nitrogentolerant species found at each site is Lecanora expallens, and the nitrogen-sensitive species found is Parmelia spp. These findings are consistent with a literature study, which stated that Lecanora is included as nitrophyte lichens and, therefore, will flourish amid the high nitrogen levels. The study also said that Parmelia species is categorized as nitrogensensitive lichen [12].

The result shows that certain species like Verrucaria maura or Parmelia spp. Only present in certain study areas, whereas Lecanora expallens, Phlyctis argena, or Herpothallon spp. dominantly present in almost all sampling regions, specifically in highly nitrogen polluted areas. This phenomenon has been discussed in previous studies, that lichen species distributes how they can tolerate nutrient enrichment (resulting in changes in $\mathrm{pH}$ ), hence depending on their acidophyte properties. However, inconsistencies in the data gathered are relatively large, for some acidophyte lichen species were present in nonpolluted areas, reciprocally [37]. It was then revised by Lewis [38] that lichen species distribution does not necessarily decide on their acidophyte properties, but by nitrogen effects on each species; hence depending on their nitrophile properties. This condition allows survival to proceed since there are only two options; to survive or to cease. Each species, including the fungi or algae component, competes in order to reach the highest succession. High nitrogen levels in the environment trigger eutrophication in algae, resulting in overgrowth of nitrophile species. Nitrophiles benefited from the polluted area, making them the dominant species amongst all [38]. Even so, the ability of lichen species to tolerate air pollutants has not been studied further. There has not been any research on nitrogen air pollution effects on certain species of lichen. Therefore, each lichen species' tolerance level that was found in this study cannot be determined yet. However, this study can be used as a base to explore other topics about the tolerance level of lichen species to nitrogen pollution. Researches around these topics can be done to understand better about lichen adaptation to specific pollutants.

This study is based on the United Kingdom Air Pollution Information System (APIS) lichen manual protocol, with several modifications made on feasibility [41]. Since oak and birch tree are hardly found in Indonesia, this study uses any trees in the respective area to prove that any trees can be used as an indicator of nitrogen pollutants. Furthermore, samples are only taken in the trunk area since it has been established before branches under different air conditions [40]. The branches are rather tall as well; hence they are troublesome to reach. Results gotten are then compared with the Nitrogen pollutant data from BMKG in June 2020, especially the information on monitoring $\mathrm{NO}_{2}$. Although the exploration is conducted on 28th September and 5th October, the air quality is assumed to be constant or stable in the following month until June 2020.

The data record was taken from two locations, in the Ministry of Defense of the Republic of Indonesia (Kementan) building and Indonesian National Monument (Monas), considering nine sites monitored and none by BMKG in Jakarta and Depok. Kementan is in the same region as Tebet (located in the South of Jakarta with $9.7 \mathrm{~km}$ distance) and the closest site with the Universitas of Indonesia (12.9 km distance). Monas is in the same region as Gelora Bung Karno (located in the Central of Jakarta with $8.7 \mathrm{~km}$ distance). The N-tolerant lichen species dominate in Universitas of Indonesia and Jakarta. This data then be converted through Nitrogen Air Quality Index (NAQI), which translates to $5 \mathrm{~N}$-polluted and 2 Very N-polluted areas. The result interprets that the air quality is very polluted in 
both regions. The data record by BMKG showed that $\mathrm{NO}_{2}$ concentration levels in Kementan and Monas were both relatively low $(0.0238 \mathrm{ppm}$ and $0.0154 \mathrm{ppm}$, respectively), but still below the Standard Quality Value $(0.08 \mathrm{ppm})$. The results from lichen and data records by BMKG are contradictory. Therefore, another calibrator is needed to support lichen data because they are highly sensitive due to the Nitrogen pollutant level change even slightly.

\section{Conclusion}

The domination of nitrogen tolerant lichen species in Jakarta and the Universitas Indonesia (Depok) shows a high level of nitrogen pollutants in the air. Out of seven study areas, two were nitrogen polluted, while the other five were significantly nitrogen polluted. However, the level of nitrogen pollution that was shown by BMKG is low. Therefore, the results proved to contradict the data records from BMKG. This research concluded that using another calibrator is needed to verify whether lichen can assess air quality in Indonesia, considering lichens are very sensitive to changes in the air's nitrogen pollutant levels. For this reason, future studies are required to gain better use of lichen biodiversity data to assess air quality.

\section{Acknowledgements}

The authors would like to thank Benedicta Gabrielle Ulibasa and Sania Prima Amanda for their help in making the previous manuscript. Furthermore, The author would like to thank R. Abdullah Reinhart Sulaiman, Nadhifa Tazkia Ramadhani, Nabila Gayatri, Jesaya, Nahdya Maulida, Yosafat, Adzra Syifa Shobrina, Ida Ayu Mas Rizky Ramadhani, Fairuz Fikri, Natasya Paulita, Laura Eve Berliana, Seruni Salsabila, Gio Putra Suyana, Meutia Admiralda Andini, Alia Farhana, and Mochamad Iqbal Dewandhi for their help in the field.

\section{References}

1. A. Plaia, and M. Ruggieri, Air quality indices: A review, Reviews in Environmental Science and Biotechnology. 10, 2 (2011)

2. A.K. Kanchan, Gorai, and P. Goyal, A Review on Air Quality Indexing System, Asian Journal of Atmospheric Environment. 9, 2 (2015)

3. D.M. Stieb, R.T. Burnett, M. Smith-Doiron, O. Brion, H.H Shin, and V. Economou, A new multipollutant, no-threshold air quality health index based on short-term associations observed in daily time-series analyses, J Air Waste Manag Assoc. 58, 3 (2008)

4. N.L.A. Rani, A. Azid, Khalit, S.I., Juahir, H., and Samsudin, M.S. Air Pollution Index Trend Analysis in Malaysia, 2010-15, J. Environ. Stud. 27, 2 (2018)

5. E. Velasco and M. Roth, Review of Singapore's air quality and greenhouse gas emissions: Current situation and opportunities, J. Air Waste Manage. Assoc. 62, 6 (2012)

6. M. Gunawan, R. Asyahira, and F.M. Sidjabat, Evaluation of Ambient Air Quality Monitoring System in Jakarta: A Literatur Review, Serambi Engineering. 5, 1 (2020)

7. K.J. Chuang, C.C. Chan, C.T. Lee, T.C. Su and C.S. Tang, The effect of urban air pollution on inflammation, oxidative stress, coagulation, and autonomic dysfunction in young adults, Am. J. Respir. Crit. Care Med. 176, 4 (2007) 
8. N. Al Naimi, P. Balakrishnan and I. Goktepe, Measurement and modelling of nitrogen dioxide $\left(\mathrm{NO}_{2}\right)$ emissions: a marker for traffic-related air pollution in Doha, Qatar, Annals of GIS. 21, 3 (2015)

9. T.M. Chen, W.G. Kuschner, J. Gokhale and S. Shofer, Outdoor Air Pollution: Nitrogen Dioxide, Sulfur Dioxide, and Carbon Monoxide Health Effects, The American Journal of the Medical Sciences. 333, 4 (2007)

10. P. Pinho, C. Branquinho, C. Cruz, T. Dias, C. Máguas, M.A. Martins-Loução, M.A. Sutton and Y.M. Tang, Using lichen functional diversity to assess the effects of atmospheric ammonia in Mediterranean woodlands, J. Appl. Ecol. 48, 5 (2011)

11. T.K. Parmar, D. Rawtani, and Y.K. Agrawal, Bioindicators: the natural indicator of environmental pollution, Front. Life Sci. 9, 2 (2016)

12. P.A. Wolseley, P.W. James, M. Theobald and M.A. Sutton, Detecting changes in epiphytic lichen communities at sites affected by atmospheric ammonia from agricultural sources', Lichenologist. 38, 2 (2006)

13. M.E. Conti and G. Cecchetti, Biological monitoring: lichens as bioindicators of air pollution assesment - a review, Environ. Pollut.. 114 (2001)

14. S. Gombert, J. Asta and M.R.D. Seaward, Assessment of lichen diversity by index of atmospheric purity (IAP), Index Of Human Impact (IHI) and other environmental factors in an urban area (Grenoble, southeast France), Science of the Total Environment. 324 (2003)

15. F. LeBlanc and J. DeSloover, Relation between industrialization and the distribution and growth of epiphytic lichens and mosses in Montreal, Can. J. Bot. 48 (1970)

16. M.W. Samsudin, L. Din, Z. Zakaria, J. Latip, T. Lihan, A.A. Jemain, and F. Samsudin, Measuring air quality using lichen mapping at Universiti Kebangsaan Malaysia (UKM) Campus, Procedia - Social and Behavioral Sciences. 59 (2012)

17. S. Will-Wolf, S. Jovan, P. Neitlich, J.E. Peck and R. Rosentreter, Lichen-based indices to quantify responses to climate and air pollution across northeastern USA', The Bryologist. 118, 1 (2015)

18. L.I. Sudirman and Y. Koesmaryono, Air quality bioindicator using the population of epiphytic macrolichens in Bogor City, West Java, HAYATI Journal of Biosciences. 22, $2(2015)$

19. B.V. Tangahu, A.A.G. Kartika and N.G. Humaira, The lichen type identification as a bioindicator of air quality of Sukolilo District in Surabaya, Indonesia, Technology Reports of Kansai University, 62, 3 (2020)

20. P.A. Wolseley, I.D. Leith, L.J. Sheppard, J.E.J. Lewis, P. Crittenden, M.A. Sutton, Guide to using a lichen based index to nitrogen air quality. UK, Field Studies Council (2013)

21. S.D.S. Bosanquet, Lichen surveys to investigate ammonia impacts. NRW Evidence Report No: 298, 126 pp, Natural Resources Wales, Bangor (2019) https://cdn.naturalresources.wales/media/689206/nrw-evidence-report-no-298-lichensurveys-to-investigate-ammonia-impacts.pdf

22. L.I Rindita, Y. Sudirman, and Koesmaryono, Air Quality Bioindicator Using the Population of Epiphytic Macrolichens in Bogor City, West Java, HAYATI Journal of Biosciences. 22, 2 (2015)

23. T. Nasriyati, Murningsih, S. Utami, Morfologi Talus Lichen Dirinaria Picta (Sw.) Schaer. Ex Clem pada Tingkat Kepadatan Lalu Lintas yang Berbeda di Kota Semarang, Jurnal Akademika Biologi, 7, 4 (2018) 
24. A.J. Silverside, 'Lepraria incana (L.) Ach (2013) http://www.lichens.lastdragon.org/Lepraria incana.html

25. Murningsih and H. Mafazaa, Types of Lichen at UNDIP Semarang, Bioma. 18, 1 (2016)

26. F. Bungartz, V.L. Dutan-Patino, J.A. Felix, The lichen genera Cryptothecia, Herpothallon and Helminthocarpon (Arthoniales) in the Galapagos Islands, Ecuador, The Lichenologist. 45, 6 (2013)

27. Hadiyanti. Sulfur content and conditions of thallus lichen Parmelia sp. and Graphis sp. on road shade trees in North Pontianak District, Probotiont. (2013)

28. P. Avant, Verrucaria maura. Tar lichen. Marine Life Information Network: Biology and Sensitivity Key Information Sub-programme (2008)

http://www.marlin.ac.uk/speciesinformation.php?speciesID $=4572$

29. H.W. Kimani, W.N. Moturi, S.T. Kariuki, Association between Anthropogenic Sources of Outdoor Air Pollution and Lichen Diversity, in Nakuru Town, Kenya' Resources and Environment. 9, 5 (2019).

30. S.M. Asih, Jumari, Murningsih. Diversity of Epiphytic Lichenes in Coffee Forest and Heterogenous Forest in Nglimut Gonoharjo Kendal, Jurnal Biologi. 2, 2 (2013)

31. T.H. Nash, B.D. Ryan, C. Gries, and F. Bungartz, Lichen Flora of the Greater Sonoran Desert Region. Vol 2 (2004)

https://ichenportal.org/cnalh/taxa/index.php?taxon=53961 andclid=201

32. A. Frisch, J. Rudolphi, and G. Thor, Herpothallon inopinatum (Arthoniaceae), a new lichen species from Mexico, Ann. Bot. Fennici. 51 (2014)

33. E.C. Pereira, M.C.B. Martins, M.L.L. Buril, R. Santiago, E.P.S. Falcão, N.H. da Silva, M.E. Legaz, and C. Vicente, Biologically-Active Compounds from Brazilian Lichens and their Affinity with Ether, Journal of Drug Design and Research. 4, 6 (2017)

34. J. Hutchinson, D. Maynard, and L. Geiser, Air Quality and Lichens - A Literature Review http://gis.nacse.org/lichenair/index.php?page=literature

35. J.M. Wakefield and B. Joydeep, Effect of air pollution on chlorophyll content and lichen morphology in Northeastern Louisiana, Evansia, 29, 4 (2012)

36. L. Seed, P. Wolseley, L. Gosling, L. Davies and S.A. Power, Modelling relationships between lichen bioindicators, air quality and climate on a national scale: Results from the UK OPAL air survey, Environ. Pollut. 182 (2013)

37. S. LaGreca and B.W. Stutzman, Distribution and ecology of Lecanora conizaeoides (Lecanoraceae) in eastern Massachusetts, The Bryologist. 193, 3 (2009)

38. J.E.J. Lewis, Biomonitoring for atmospheric nitrogen pollution using epiphytic lichens and bryophytes (2012) PhD Thesis (http://etheses.nottingham.ac.uk/3573/).

39. Centre for Ecology and Hydrology, Monitoring air quality using lichens - field guide and app (2016) http://www.apis.ac.uk/lichen-app/info

40. Centre for Ecology and Hydrology, Lichen Online Manual (2016)

http://www.apis.ac.uk/lichen-app/info

41. In, J. Introduction of a pilot study. Korean J. Anesthesiol. 70, 6 (2017). 